ARTICLE

\title{
Bisguanidinium dinuclear oxodiperoxomolybdosulfate ion pair-catalyzed enantioselective sulfoxidation
}

Lili Zong ${ }^{1}$, Chao Wang ${ }^{1}$, Adhitya Mangala Putra Moeljadi ${ }^{1}$, Xinyi Ye ${ }^{1}$, Rakesh Ganguly ${ }^{1}$, Yongxin Li ${ }^{1}$, Hajime Hirao ${ }^{1}$ $\&$ Choon-Hong $\operatorname{Tan}^{1}$

Catalytic use of peroxomolybdate for asymmetric transformations has attracted increasing attention due to its catalytic properties and application in catalysis. Herein, we report chiral bisguanidinium dinuclear oxodiperoxomolybdosulfate $[\mathbf{B G}]^{2+}\left[\left(\mu-\mathrm{SO}_{4}\right) \mathrm{Mo}_{2} \mathrm{O}_{2}\left(\mu-\mathrm{O}_{2}\right)_{2}\left(\mathrm{O}_{2}\right)_{2}\right]^{2-}$ ion pair, as a catalyst for enantioselective sulfoxidation using aqueous $\mathrm{H}_{2} \mathrm{O}_{2}$ as the terminal oxidant. The ion pair catalyst is isolatable, stable and useful for the oxidation of a range of dialkyl sulfides. The practical utility was illustrated using a gram-scale synthesis of armodafinil, a commercial drug, with the catalyst generated in situ from $0.25 \mathrm{~mol} \%$ of bisguanidinium and $2.5 \mathrm{~mol} \%$ of $\mathrm{Na}_{2} \mathrm{MoO}_{4} \cdot 2 \mathrm{H}_{2} \mathrm{O}$. Structural characterization of this ion pair catalyst has been successfully achieved using single-crystal $\mathrm{X}$-ray crystallography.

\footnotetext{
${ }^{1}$ Division of Chemistry and Biological Chemistry, School of Physical and Mathematical Sciences, Nanyang Technological University, 21 Nanyang Link, Singapore 637371, Singapore. Correspondence and requests for materials should be addressed to H.H. (email: hirao@ntu.edu.sg) or to C.-H.T. (email: choonhong@ntu.edu.sg).
} 
M etalloenzymes containing molybdenum, responsible for nitrogen and sulfur metabolism ${ }^{1-4}$, continue to fuel interest in the exploration of novel molybdenum complexes with catalytic activities. Various neutral coordination complexes of $\mathrm{Mo}(\mathrm{VI})$ containing chiral organic ligands have been synthesized and studied extensively for enantioselective reactions $s^{5-11}$. In particular, one interesting example of highly enantioselective sulfoxidation of alkyl aryl sulfides was demonstrated using a complex derived from $\mathrm{MoO}_{2}(\mathrm{acac})_{2}$ and chiral bis-hydroxamic acids ${ }^{12}$. In contrast to their neutral counterparts, there have been no successful attempts to utilize peroxomolybdate ${ }^{13}$ for asymmetric reactions, even though many of these species have been comprehensively characterized.

It is well known that peroxomolybdates are formed on the treatment of molybdate salts with aqueous $\mathrm{H}_{2} \mathrm{O}_{2}$ oxidant ${ }^{14,15}$. Monomeric, oligomeric and polymeric peroxomolybdate species could be generated under similar conditions (Fig. 1) ${ }^{14}$. The addition of different organic ligands can further increase the structural and functional diversity of peroxomolybdate complexes $^{16-18}$. Other ligands such as silanol ${ }^{19}$, phosphate ${ }^{20}$, arsenate ${ }^{21}$ and sulfate ${ }^{22-25}$ have been used to bridge molybdates to construct dinuclear or trinuclear peroxomolybdate complexes. Peroxomolybdates species have been shown to be excellent catalysts for the oxidation of numerous substrates, including alkenes, alcohols ${ }^{26}$ and sulfides. The complexity of peroxomolybdates is thus recognized to be a challenging obstacle for elaborating them into highly enantioselective catalysts.

We have recently developed pentanidium ${ }^{27-30}$ and dicationic bisguanidinium (BG) as efficient phase-transfer ${ }^{31,32}$ and ion pair catalysts ${ }^{33-37}$. We have utilized bisguanidinium permanganate ion pair catalyst for the enantioselective oxidation of alkenes ${ }^{38}$. The precise stereocontrol exhibited by bisguanidinium encouraged us to explore other anionic metallic species for asymmetric transformations ${ }^{39}$. Herein, we describe our serendipitous discovery of chiral bisguanidinium dinuclear oxodiperoxomolybdosulfate $[\mathbf{B G}]^{2+}\left[\left(\mu-\mathrm{SO}_{4}\right) \mathrm{Mo}_{2} \mathrm{O}_{2}\left(\mu-\mathrm{O}_{2}\right)_{2}\left(\mathrm{O}_{2}\right)_{2}\right]^{2-}$ ion pair catalyst (Fig. 2). This ion pair catalyst is stable and isolatable or it can be generated in situ. In a continuation of our current efforts towards developing practical approaches to enantiopure sulfoxides ${ }^{29,40,41}$, we report a simple and scalable methodology for enantioselective sulfoxidation using this ion pair catalyst ${ }^{42-45}$.

\section{Results}

Catalytic application of molybdate in sulfoxidation. At the onset of this work, we realized that we were unable to approach enantiopure 2-sulfinyl esters through enantioselective alkylation of sulfenate anion, as the reaction was incompatible with $\alpha$-halogenated carboxylates (Supplementary Fig. 1) ${ }^{29}$. We were attracted to the low cost and easy accessibility of molybdate salts and thus we attempted to investigate the direct sulfoxidation of 2-sulfanyl acetate, by utilizing a catalytic amount of molybdate salts and aqueous $\mathrm{H}_{2} \mathrm{O}_{2}$ as terminal oxidant. Methyl 2-(benzhydrylsulfanyl)acetate $\mathbf{2 a}$ was chosen as the model substrate (Table 1), since 2-sulfinyl acetate $\mathbf{3 a}$ could be easily transformed to armodafinil, a commercial drug used for the treatment of narcolepsy and shift work sleep disorder ${ }^{46-48}$.

When the reaction was performed in the presence of $1 \mathrm{~mol} \%$ of $(S, S)-1 \mathrm{a}, 5 \mathrm{~mol} \%$ of $\left(\mathrm{NH}_{4}\right)_{6} \mathrm{Mo}_{7} \mathrm{O}_{24} \cdot 4 \mathrm{H}_{2} \mathrm{O}$ and 1.05 equiv. $35 \%$ aqueous $\mathrm{H}_{2} \mathrm{O}_{2}$, poor yield and no enantioselectivity were observed (Table 1, entry 1). With the addition of acetic acid ${ }^{49}$, the enantioselectivity was slightly improved, albeit with low yield (entries 2 and 3 ). Using trifluoroacetic acid as additive, a marked enhancement of the reactivity was achieved, but with negligible enantioselectivity (entry 4). With the addition of sodium or potassium hydrogen sulfate, we observed significant improvement of yield, as well as enantioselectivity (entries 5 and 6$)^{50,51}$. Switching to other additives, such as dihydrogen phosphate or hydrogen phosphate led to poor results (entries 7 and 8). Further investigation of reaction parameters (entries 9-14), such as the source of molybdate, solvent and stoichiometry of $\mathrm{KHSO}_{4}$, led to the enhancement of reactivity, as well as enantioselectivity (entry 14, 93\% ee; Supplementary Table 1). The optimal condition was established by lowering the

\section{a}

$(R, R)-1 \mathrm{a},[\mathrm{X}]^{2-}=2 \mathrm{Cl}^{-}$

$(R, R)-1 \mathbf{b},[\mathrm{X}]^{2-}=$

$\left[\left(\mu_{2}-\mathrm{SO}_{4}\right)\left\{\mathrm{MO}_{2} \mathrm{O}_{2}\left(\mu_{2}-\mathrm{O}_{2}\right)_{2}\left(\mathrm{O}_{2}\right)_{2}\right\}\right]^{2-}$
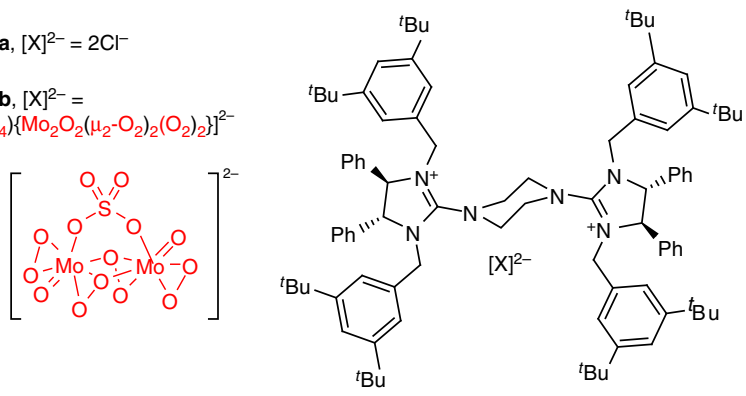

b

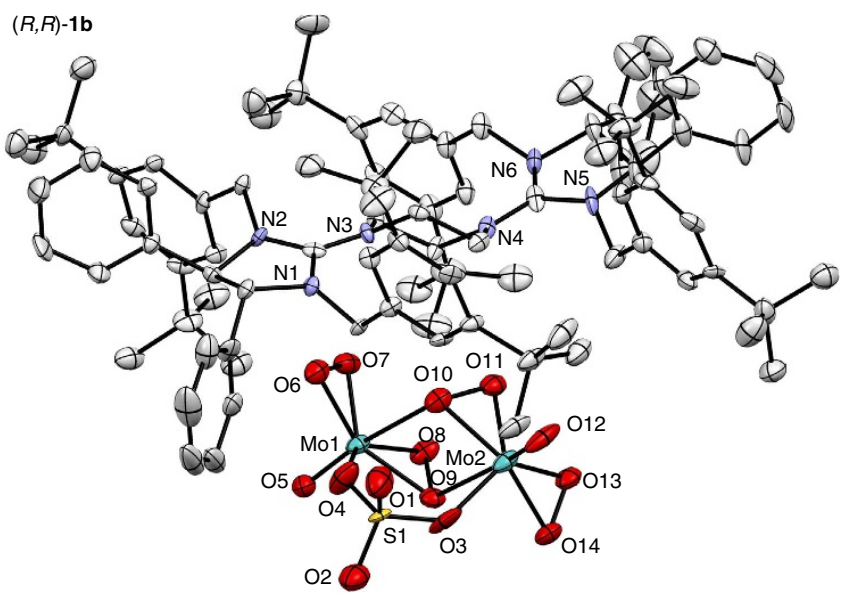

Figure 2 | Bisguanidinium ion pairs $(R, R)-1 \mathrm{a}$ and $(R, R)-1 \mathbf{b}$. (a) Structure of bisguanidinium salts. (b) $\mathrm{X}$-ray crystallographic structure of $[\mathbf{B G}]^{2+}$ $\left[\left(\mu-\mathrm{SO}_{4}\right) \mathrm{Mo}_{2} \mathrm{O}_{2}\left(\mu-\mathrm{O}_{2}\right)_{2}\left(\mathrm{O}_{2}\right)_{2}\right]^{2-}(R, R)-\mathbf{1 b}$ (ellipsoids at $50 \%$ probability).
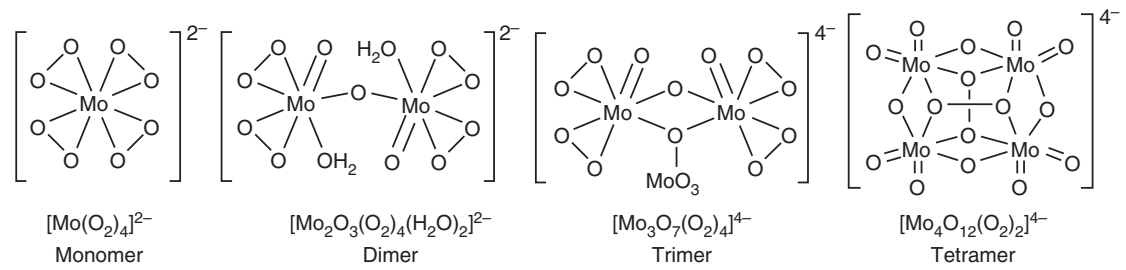

Figure 1 | Examples of peroxomolybdate complexes. Monomeric, dimeric, trimeric and tetrameric peroxomolybdates generated by treating molybdate with $\mathrm{H}_{2} \mathrm{O}_{2}$ 
Table 1 | Optimization of bisguanidinium-catalyzed asymmetric sulfoxidation of $2 a$.

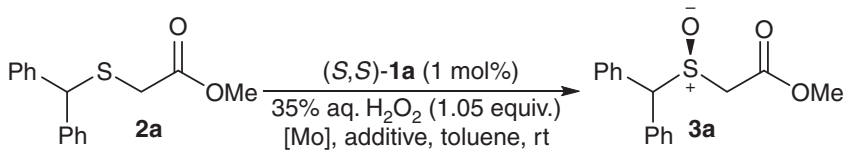

\begin{tabular}{|c|c|c|c|c|c|}
\hline Entry & [Mo] (5 mol\%) & Additive (x equiv.) & Time (h) & Yield $(\%)^{\star}$ & ee $(\%)^{\dagger}$ \\
\hline 1 & $\left(\mathrm{NH}_{4}\right)_{6} \mathrm{Mo}_{7} \mathrm{O}_{24} \cdot 4 \mathrm{H}_{2} \mathrm{O}$ & - & 24 & 15 & 0 \\
\hline $2^{\ddagger}$ & $\left(\mathrm{NH}_{4}\right)_{6} \mathrm{Mo}_{7} \mathrm{O}_{24} \cdot 4 \mathrm{H}_{2} \mathrm{O}$ & $\mathrm{CH}_{3} \mathrm{CO}_{2} \mathrm{H}(1.0)$ & 24 & 0 & 0 \\
\hline 3 & $\left(\mathrm{NH}_{4}\right)_{6} \mathrm{Mo}_{7} \mathrm{O}_{24} \cdot 4 \mathrm{H}_{2} \mathrm{O}$ & $\mathrm{CH}_{3} \mathrm{CO}_{2} \mathrm{H}(1.0)$ & 24 & 14 & 20 \\
\hline 4 & $\left(\mathrm{NH}_{4}\right)_{6} \mathrm{Mo}_{7} \mathrm{O}_{24} \cdot 4 \mathrm{H}_{2} \mathrm{O}$ & $\mathrm{CF}_{3} \mathrm{CO}_{2} \mathrm{H}(1.0)$ & 8 & 80 & 4 \\
\hline 5 & $\left(\mathrm{NH}_{4}\right)_{6} \mathrm{Mo}_{7} \mathrm{O}_{24} \cdot 4 \mathrm{H}_{2} \mathrm{O}$ & $\mathrm{NaHSO}_{4}(1.0)$ & 19 & 99 & 69 \\
\hline 6 & $\left(\mathrm{NH}_{4}\right)_{6} \mathrm{Mo}_{7} \mathrm{O}_{24} \cdot 4 \mathrm{H}_{2} \mathrm{O}$ & $\mathrm{KHSO}_{4}(1.0)$ & 19 & 99 & 75 \\
\hline 7 & $\left(\mathrm{NH}_{4}\right)_{6} \mathrm{Mo}_{7} \mathrm{O}_{24} \cdot 4 \mathrm{H}_{2} \mathrm{O}$ & $\mathrm{LiH}_{2} \mathrm{PO}_{4}(1.0)$ & 19 & 50 & 40 \\
\hline 8 & $\left(\mathrm{NH}_{4}\right)_{6} \mathrm{Mo}_{7} \mathrm{O}_{24} \cdot 4 \mathrm{H}_{2} \mathrm{O}$ & $\mathrm{Na}_{2} \mathrm{HPO}_{4}(1.0)$ & 19 & 28 & 0 \\
\hline 9 & $\mathrm{Li}_{2} \mathrm{MoO}_{4}$ & $\mathrm{KHSO}_{4}(1.0)$ & 3 & 85 & 88 \\
\hline 10 & $\mathrm{~K}_{2} \mathrm{MoO}_{4}$ & $\mathrm{KHSO}_{4}(1.0)$ & 2 & 99 & 86 \\
\hline 11 & $\mathrm{Na}_{2} \mathrm{MoO}_{4} \cdot 2 \mathrm{H}_{2} \mathrm{O}$ & $\mathrm{KHSO}_{4}(1.0)$ & 2 & 99 & 88 \\
\hline 12 & $\mathrm{Na}_{2} \mathrm{MoO}_{4} \cdot 2 \mathrm{H}_{2} \mathrm{O}$ & $\mathrm{KHSO}_{4}(0.5)$ & 2 & 99 & 89 \\
\hline 13 & $\mathrm{Na}_{2} \mathrm{MoO}_{4} \cdot 2 \mathrm{H}_{2} \mathrm{O}$ & $\mathrm{KHSO}_{4}(0.25)$ & 2 & 99 & 83 \\
\hline $14^{\S}$ & $\mathrm{Na}_{2} \mathrm{MoO}_{4} \cdot 2 \mathrm{H}_{2} \mathrm{O}$ & $\mathrm{KHSO}_{4}(0.5)$ & 1 & 99 & 93 \\
\hline $15^{\S, \|}$ & $\mathrm{Na}_{2} \mathrm{MoO}_{4} \cdot 2 \mathrm{H}_{2} \mathrm{O}$ & $\mathrm{KHSO}_{4}(0.5)$ & 1 & 99 & 94 \\
\hline
\end{tabular}

temperature to $0{ }^{\circ} \mathrm{C}$ and using just $1 \mathrm{~mol} \%$ of $(S, S)$-1a together with $2.5 \mathrm{~mol} \% \mathrm{Na}_{2} \mathrm{MoO}_{4} \cdot 2 \mathrm{H}_{2} \mathrm{O}$ in ${ }^{i} \mathrm{Pr}_{2} \mathrm{O}$, affording 2-sulfinyl acetate $3 \mathbf{a}$ in $99 \%$ yield with $94 \%$ ee (entry 15). The absolute configuration of $\mathbf{3 a}$ was confirmed to be $S$ through comparison with the reported data ${ }^{46}$.

Substrate scope of various sulfides using $(S, S)-1 \mathrm{a}$. The reaction scope was examined using a series of substrates with a relatively low reactivity, in which the electron density of sulfur is reduced, due to strong electron-withdrawing groups like ester, ketone and nitrile (Table 2). The reactions performed efficiently and were generally completed within $1 \mathrm{~h}$. For benzyl 2-sulfanylacetates with different substituents on the aromatic ring, dialkyl sulfoxides 3b-3i were obtained in high yields and excellent enantioselectivities. Sulfoxide $\mathbf{3 j}$ bearing 2 -thienyl was obtained in high yield and good enantioselectivity without oxidation at the thiophene. With a slight variation of reaction conditions, using 0.25 equivalent of $\mathrm{KHSO}_{4}$ and $2.5 \mathrm{~mol} \%$ of $\mathrm{K}_{2} \mathrm{MoO}_{4}$, various aromatic 2-sulfanylacetates were efficiently converted to alkyl aryl sulfoxides $\mathbf{3 k - 3 q}$ in high yields with good enantioselectivities. For the oxidation of sulfide-bearing para-OMe substituent, leading to sulfoxide 31, slight over-oxidation to sulfone was observed. For a less reactive substrate $\mathbf{2 r}$, the reaction was conducted at room temperature using 1.5 equiv. $\mathrm{H}_{2} \mathrm{O}_{2}$, affording sulfoxide $3 \mathbf{r}$ with good enantioselectivity. With less favourable substrates such as tert-butyl substituted 2-sulfanyl acetate 2 s, low enantioselective induction was observed (Table 2, 3s).

To further explore the scope, a diverse range of substrates bearing different functional groups were examined (Table 2, 3t-3y). 3-Sulfinyl propanoate $3 \mathbf{t}$ was produced with excellent enantioselectivity. Sulfoxides $\mathbf{3 u}-\mathbf{3 y}$ bearing amide, ketone, acrylate, nitrile and aldehyde moieties were furnished with good to excellent enantioselectivities. The absolute configurations of 3f and 3o were confirmed to be $R$ and $\mathrm{S}$, respectively, using single-crystal X-ray diffraction; thus, absolute configurations of sulfoxides $\mathbf{3}$ were assigned by analogy to either $\mathbf{3 f}$ or $\mathbf{3 o}$. The practical utility was successfully demonstrated using a gram-scale synthesis of $(R)$-modafinil (armodafinil), a commercial drug, using $0.25 \mathrm{~mol} \%$ of $(R, R)$-1a (Fig. 3).

Identification and characterization of ion pair $(R, R)-1 \mathbf{b}$. We attempted to identify the reactive catalytic species by mimicking the reaction conditions in the absence of sulfide substrate (Fig. 4). After a simple workup procedure, $(R, R)$-1b was isolated and a single crystal suitable for X-ray diffraction was grown by vapour diffusion of $\mathrm{Et}_{2} \mathrm{O}$ into a dimethylformamide (DMF) solution of $(R, R)-\mathbf{1 b}$. The structure of $(R, R)$-1 b was fully characterized using $\mathrm{X}$-ray analysis (Fig. $2 \mathrm{~b}$ ), ${ }^{95}$ Mo nuclear magnetic resonance (NMR) (Fig. 5b) and fourier transform-infrared spectroscopy (FT-IR) (Supplementary Fig. 2).

The achiral anionic metallic species $\left[\left(\mu-\mathrm{SO}_{4}\right) \mathrm{Mo}_{2} \mathrm{O}_{2}\right.$ $\left.\left(\mu-\mathrm{O}_{2}\right)_{2}\left(\mathrm{O}_{2}\right)_{2}\right]^{2-}$ is revealed by $\mathrm{X}$-ray crystallography to be embedded within the chiral cavity formed by two side arms of the chiral bisguanidinium dication (Fig. 2b). The coordination geometry surrounding the Mo was clearly elucidated (Fig. 5a). The $\mathrm{SO}_{4}^{2-}$ ligand plays a crucial role in constructing the dimeric symmetric structure. Each Mo centre comprises one bridging peroxo ligand, one side-on peroxo group and a terminal oxo ligand, with the sulfate group acting as a bipodal ligand to the two Mo atoms. Each Mo atom is 7-coordinated with oxygen atoms in a pentagonal bipyramidal arrangement. The two associated pentagonal bipyramids share one edge $\left[\mathrm{O}_{9}-\mathrm{O}_{10}\right]$ and the two Mo atoms are connected by two $\mu-\eta^{1}: \eta^{2}$ peroxo-bridges, $\left[\mathrm{O}_{8}-\mathrm{O}_{9}\right.$ and $\left.\mathrm{O}_{11}-\mathrm{O}_{10}\right]$. Both $\mathrm{Mo}_{1}-\mathrm{O}_{5}$ and $\mathrm{Mo}_{2}-\mathrm{O}_{12}$ bonds have the same length $(1.659(7) \AA)$ that falls in a typical range for the $\mathrm{Mo}=\mathrm{O}$ bond. Generally, the bridging peroxo $\mathrm{O}_{8}-\mathrm{O}_{9}(1.482(9) \AA)$ and $\mathrm{O}_{10}-\mathrm{O}_{11}(1.473(10) \AA)$ bond lengths are slightly longer than the other side-on peroxo $\mathrm{O}_{6}-\mathrm{O}_{7}(1.458(10) \AA)$ and $\mathrm{O}_{13}-\mathrm{O}_{14}$ $(1.467(10) \AA)$ bond lengths. ${ }^{95} \mathrm{Mo}$ NMR spectrum of $(R, R)-1 \mathbf{b}$ was also obtained in $\mathrm{DMF}-\mathrm{d}_{7}$ at $22^{\circ} \mathrm{C}$, using $2 \mathrm{M}$ $\mathrm{Na}_{2} \mathrm{MoO}_{4} \cdot 2 \mathrm{H}_{2} \mathrm{O}$ solution in $\mathrm{D}_{2} \mathrm{O}$ as an external reference (assigned to 0 p.p.m.). The chemical shift at -199.3 p.p.m. is characteristic of oxodiperoxomolybdate species (Fig. 5b) ${ }^{52}$.

We found that $(R, R)-\mathbf{1 b}$ (1.0 equiv.), prepared using the method in Fig. 4, can be used directly as the oxidant for 
Table 2 | Substrate scope of sulfides in asymmetric sulfoxidation.

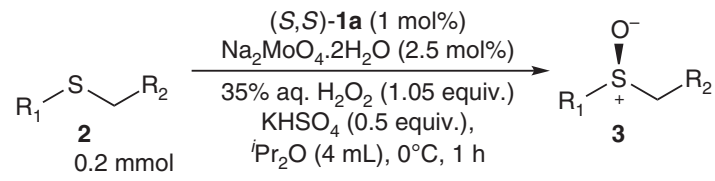<smiles>CC(C)(C)OCC([O-])[SH]([O-])Cc1ccccc1</smiles>

3b, $99 \%$ yield, $90 \%$ ee<smiles>CCC(C)(C)OC(=O)C[S]([O-])Cc1ccc(Cl)cc1</smiles>

3f, $92 \%$ yield, $91 \%$ ee<smiles>CCCOC(=O)C[SH]([O-])Cc1cccs1</smiles>

3j, $94 \%$ yield, $89 \%$ ee $^{\star}$<smiles>CCC(C)OC(=O)C[S+]([O-])c1ccc(Cl)cc1</smiles>

3n, $93 \%$ yield, $90 \%$ ee<smiles>CCCCOC(=O)C[S+]([O-])c1nc2ccccc2s1</smiles>

$3 \mathbf{r}, 79 \%$ yield, $74 \%$ ee<smiles>Cc1ccc(C(=O)C[S+]([O-])Cc2ccccc2)cc1</smiles>

3v, $99 \%$ yield, $90 \%$ ee<smiles>Cc1ccc(C[Sb]([O-])CC(=O)OCc2ccccc2)cc1</smiles>

3c, $92 \%$ yield, $92 \%$ ee<smiles>CCCCC(=O)C[S+]([O-])Cc1ccccc1C</smiles>

$3 \mathbf{g}, 98 \%$ yield, $92 \%$ ee<smiles>CCCCOC(=O)C[S+]([O-])c1ccccc1</smiles>

3k, $91 \%$ yield, $86 \%$ ee<smiles>CC(C)(C)OC(=O)C[S+]([O-])c1ccc(Br)cc1</smiles>

3o, $95 \%$ yield, $91 \%$ ee<smiles>CC(C)(C)OC(=O)C[S+]([O-])C(C)(C)C</smiles>

3s, $83 \%$ yield, $37 \% \mathrm{ee}^{\star}$<smiles>CCOC(=O)C=CC[S+]([O-])Cc1ccccc1</smiles>

$3 w, 84 \%$ yield, $77 \% \mathrm{ee}^{\dagger}$<smiles>COc1ccc(C[S]([O-])CC(=O)OC(C)(C)C)cc1</smiles>

3d, $96 \%$ yield, $83 \%$ ee*<smiles>CCCCOC(=O)C[SH]([O-])Cc1ccccc1Cl</smiles>

$3 \mathrm{~h}, 98 \%$ yield, $93 \%$ ee<smiles>CCCCC(=O)O[C-]([O-])c1ccc(OC)cc1</smiles>

3I, $94 \%$ yield, $79 \%$ ee<smiles>COc1ccccc1[S+]([O-])CC(=O)OCC(C)(C)C</smiles>

$3 p, 99 \%$ yield, $89 \% \mathrm{ee}^{*},{ }^{\dagger, \neq}$<smiles>CC(=O)CC[SH]([O-])C(c1ccccc1)c1ccccc1</smiles>

3t, $88 \%$ yield, $94 \% \mathrm{ee}^{\dagger}$<smiles>N#CC[S]([O-])Cc1ccccc1</smiles><smiles>CCCOC(=O)C[S+]([O-])Cc1ccc(F)cc1</smiles>

3e, $94 \%$ yield, $96 \%$ ee<smiles>CCCCOC(=O)C[S+]([O-])Cc1ccccc1Br</smiles>

3i, $99 \%$ yield, $93 \%$ ee<smiles>CCCCC(=O)C[SH]([O-])c1ccc(F)cc1</smiles>

$3 \mathrm{~m}, 93 \%$ yield, $89 \% \mathrm{ee}^{\star},{ }^{\dagger, \ddagger}$<smiles>CCCCC(=O)C[SH]([O-])c1cccc2ccccc12</smiles>

3q, $97 \%$ yield, $83 \%$ ee<smiles>NC(=O)C[SH]([O-])C(c1ccccc1)c1ccccc1</smiles>

$3 u, 96 \%$ yield, $82 \%$ ee $^{\dagger}$<smiles>C[Sb]([O-])c1ccc(C=O)cc1</smiles>

$3 y, 82 \%$ yield, $65 \% \mathrm{ee}^{\dagger, \neq}$

Conditions: reaction was performed with $0.2 \mathrm{mmol}$ of $\mathbf{2}, \mathrm{H}_{2} \mathrm{O}_{2}$ (1.05 equiv.), $\mathrm{KHSO}_{4}$ (0.5 equiv.), $2.5 \mathrm{~mol}^{2} \mathrm{Na}_{2} \mathrm{MoO}_{4} \cdot 2 \mathrm{H}_{2} \mathrm{O}, 1 \mathrm{~mol} \%(\mathrm{~S}, \mathrm{~S})-\mathbf{1 a}$ in $4.0 \mathrm{ml}$ of solvent at $0{ }^{\circ} \mathrm{C}$

${ }^{*} \mathrm{Bu}_{2} \mathrm{O}$ as the solvent.

$+\mathrm{K}_{2} \mathrm{MoO}_{4}$ as $\left[\mathrm{MoO}_{4}\right]^{2-}$ source.

\pm 0.25 equiv. of $\mathrm{KHSO}_{4}$

\$The reaction was conducted at room temperature for $24 \mathrm{~h}$ using 1.5 equiv. of $35 \%$ aqueous $\mathrm{H}_{2} \mathrm{O}_{2}$

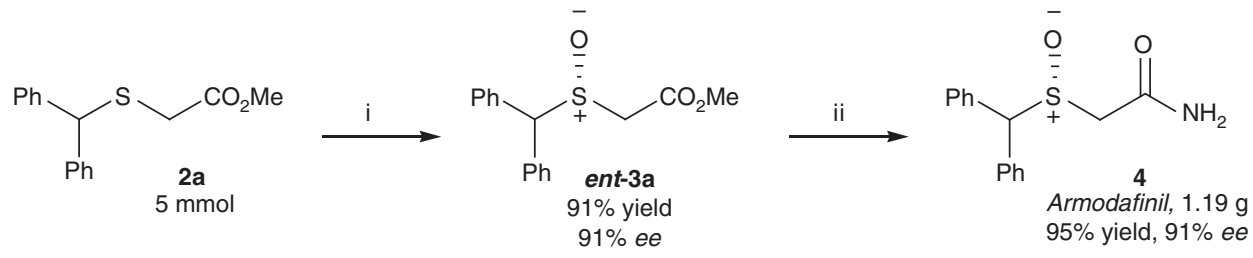

Figure 3 | Gram-scale synthesis of $\boldsymbol{R}$-modafinil (armodafinil). Reaction conditions: (i) $(R, R)-\mathbf{1 a}(0.25 \mathrm{~mol} \%), \mathrm{Na}_{2} \mathrm{MoO}_{4} \cdot 2 \mathrm{H}_{2} \mathrm{O}(2.5 \mathrm{~mol} \%), 35 \%$ aq. $\mathrm{H}_{2} \mathrm{O}_{2}$ (1.05 equiv.), $\mathrm{KHSO}_{4}$ (0.5 equiv.), ${ }^{n} \mathrm{Bu}_{2} \mathrm{O}(0.05 \mathrm{M})$, rt, $8 \mathrm{~h}$; (ii) $\mathrm{NH}_{3}(10.0$ equiv., $2 \mathrm{M}$ in $\mathrm{MeOH}$ ), rt, $24 \mathrm{~h}$.

sulfoxidation, without additional aqueous $\mathrm{H}_{2} \mathrm{O}_{2}$, providing sulfoxide ent-3a in $90 \%$ yield and $80 \%$ ee in $0.5 \mathrm{~h}$ (Fig. 6a, equation 1). This result indicates that $(R, R)-\mathbf{1 b}$ is the actual oxidizing specie providing high enantiodiscrimination. Utilizing
0.25 equiv. $(R, R)-\mathbf{1 b}$ led to the formation of ent-3a in $50 \%$ yield in $24 \mathrm{~h}$ with $31 \%$ ee (Fig. 6a, equation 2), demonstrating that two out of four peroxo moieties on $(R, R)-\mathbf{1 b}$ are active oxygen donors, as two equivalent of active oxygen from $(R, R)$-1 $\mathbf{b}$ are transferred to 


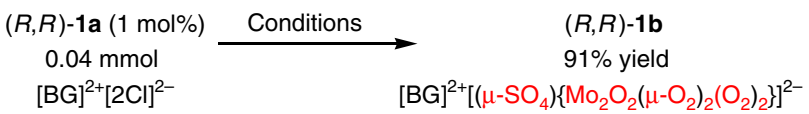

Figure 4 | Preparation of $[\mathbf{B G}]^{\mathbf{2}}+\mathbf{[}\left(\boldsymbol{\mu}-\mathbf{S O}_{\mathbf{4}}\right) \mathbf{M o}_{\mathbf{2}} \mathbf{O}_{\mathbf{2}}\left(\boldsymbol{\mu}-\mathbf{O}_{\mathbf{2}}\right)_{\mathbf{2}}\left(\mathbf{O}_{\mathbf{2}} \mathbf{~} \mathbf{2}^{\mathbf{2}} \mathbf{2}^{-}(\boldsymbol{R}, \boldsymbol{R})-\mathbf{1 b}\right.$. Conditions: $\mathrm{Na}_{2} \mathrm{MoO}_{4} \cdot 2 \mathrm{H}_{2} \mathrm{O}(2.5 \mathrm{~mol} \%), 35 \%$ aq. $\mathrm{H}_{2} \mathrm{O}_{2}(1.0$ equiv. $)$, $\mathrm{KHSO}_{4}$ (0.5 equiv.) or $\mathrm{H}_{2} \mathrm{SO}_{4}$ ( 0.25 equiv.), $\mathrm{Et}_{2} \mathrm{O}(2 \mathrm{ml}), \mathrm{rt}, 2 \mathrm{~h}$.
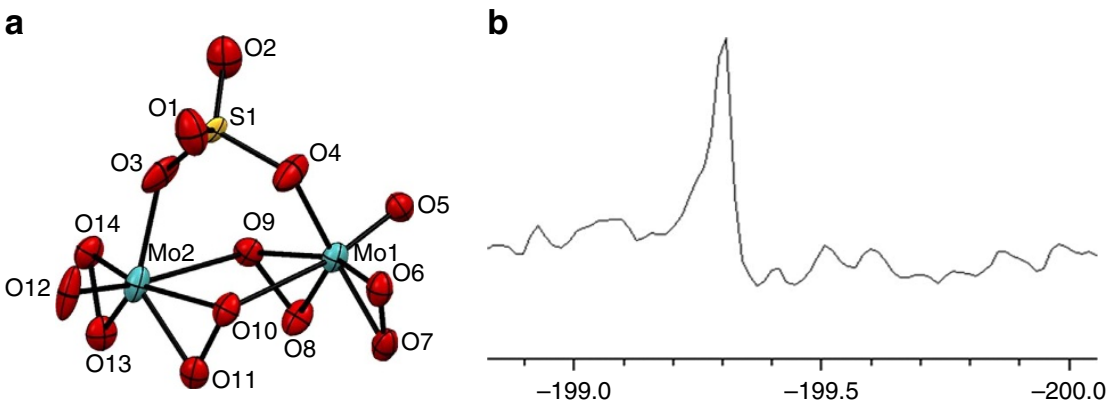

Figure 5 | Characterization of the anionic cluster $\left[\left(\boldsymbol{\mu}-\mathbf{S O}_{\mathbf{4}}\right) \mathbf{M o}_{\mathbf{2}} \mathbf{O}_{\mathbf{2}}\left(\boldsymbol{\mu}-\mathbf{O}_{\mathbf{2}} \mathbf{~} \mathbf{2}_{\mathbf{2}}\left(\mathbf{O}_{\mathbf{2}}\right)_{\mathbf{2}}\right]\right.$ in $(\boldsymbol{R}, \boldsymbol{R})-\mathbf{1 b}$. $(\mathbf{a})$ ORTEP view of $\left[\left(\boldsymbol{\mu}-\mathrm{SO}_{4}\right) \mathrm{Mo}_{2} \mathrm{O}_{2}\left(\mu-\mathrm{O}_{2}\right)_{2}\left(\mathrm{O}_{2}\right)_{2}\right]^{2-}$ dianion in $(R, R)-\mathbf{1 b}$ with the atom numbering scheme. (b) ${ }^{95} \mathrm{Mo} N M R$ spectrum of $(R, R)-\mathbf{1 b}$ in DMF- $\mathrm{d}_{7}\left(0.05 \mathrm{M}, 22{ }^{\circ} \mathrm{C}\right)$.

a

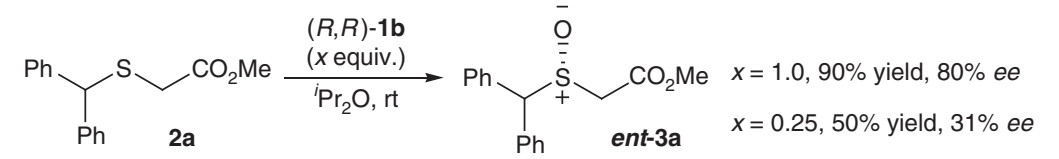

b

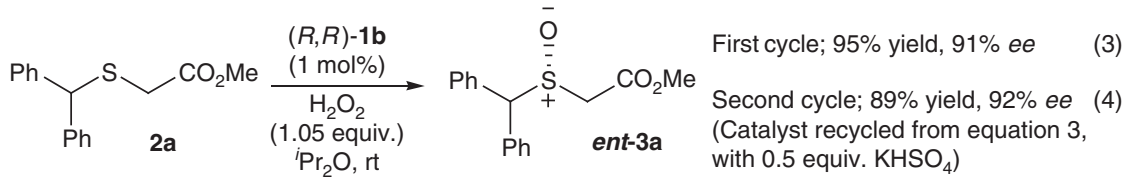

Figure 6 | Mechanistic insights. (a) $[\mathbf{B G}]^{2+}\left[\left(\mu-\mathrm{SO}_{4}\right) \mathrm{Mo}_{2} \mathrm{O}_{2}\left(\mu-\mathrm{O}_{2}\right)_{2}\left(\mathrm{O}_{2}\right)_{2}\right]^{2-}(R, R)-\mathbf{1 b}$ as the sole oxidant. (b) 1 mol\% $(R, R)-1 \mathbf{b}$ as catalyst.

the sulfides ${ }^{53}$. The second oxygen transfer is slower and less enantioselective than the first. As expected, $(R, R)-\mathbf{1 b}$ can be used catalytically in the presence of $\mathrm{H}_{2} \mathrm{O}_{2}$, providing sulfoxide ent-3a in $95 \%$ yield with $91 \%$ ee at a loading of $1 \mathrm{~mol} \%$ (Fig. $6 \mathrm{~b}$, equation 3 ). This result is comparable to the reaction, in which this active catalyst is prepared in situ from $(R, R)-\mathbf{1 a}$ (Fig. 3). The catalyst can be recycled from the reaction (Fig. $6 \mathrm{~b}$, equation 3 ) and used for a second round of reaction, but an additional amount of 0.5 equiv. of $\mathrm{KHSO}_{4}$ must be added to restore the reactivity and enantioselectivity (Fig. 6b, equation 4 ).

Computational studies of $(R, R)-\mathbf{1 b}$ using the ONIOM method revealed that a more stable ion-pairing arrangement, with the distance between the anionic cluster and the cationic bisguanidinium noticeably reduced compared with that in the crystal structure (Fig. 7). As a result of this rearrangement, approach of the substrate to most of the peroxo-oxygen atoms is obstructed by bisguanidinium and sulphate groups. Only one of side-on peroxo-oxygen atoms (marked as $\mathrm{O}_{14}$ in Fig. 7) remains accessible for reaction. This is consistent with the experimentally observed high enantioselectivity, since restricted access to secondary reaction sites will result in a reaction with higher selectivity.

Reaction selectivity was evaluated using $50 \mathrm{~mol} \%$ tetrabutylammonium hydrogen sulfate $\left({ }^{n} \mathrm{Bu}_{4} \mathrm{NHSO}_{4}\right)$ as an achiral ion-pairing reagent (Fig. 8). A high level of enantiocontrol can still be achieved, which indicates ion pairing interaction between chiral bisguanidinium and dinuclear oxodiperoxomolybdosulfate anion $\left[\left(\mu-\mathrm{SO}_{4}\right) \mathrm{Mo}_{2} \mathrm{O}_{2}\left(\mu-\mathrm{O}_{2}\right)_{2}\left(\mathrm{O}_{2}\right)_{2}\right]^{2-}$ accelerates the reaction rate significantly over tetrabutylammonium, promoting the

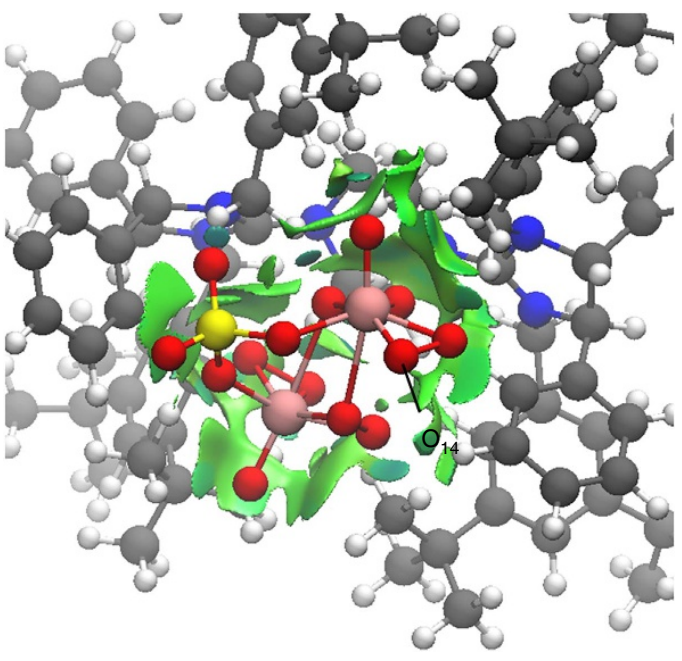

Figure 7 | Geometry optimization of ion pair $(R, R)$-1b with ONIOM method. Structure of $(R, R)$-1b obtained from ONIOM geometry optimization, where atoms are color-coded as follows: C (grey), N (blue), $\mathrm{H}$ (white), $\mathrm{S}$ (yellow), $\mathrm{O}$ (red) and $\mathrm{Mo}$ (pink). The displayed $\mathrm{NCl}$ surface of bisguanidinium indicates interactions between the anionic cluster $\left[\left(\mu-\mathrm{SO}_{4}\right) \mathrm{Mo}_{2} \mathrm{O}_{2}\left(\mu-\mathrm{O}_{2}\right)_{2}\left(\mathrm{O}_{2}\right)_{2}\right]$ and bisguanidinium.

reaction through the desired asymmetric pathway. The stereoinduction observed in the current methodology may be ascribed to ion pairing interaction and other non-covalent interactions 


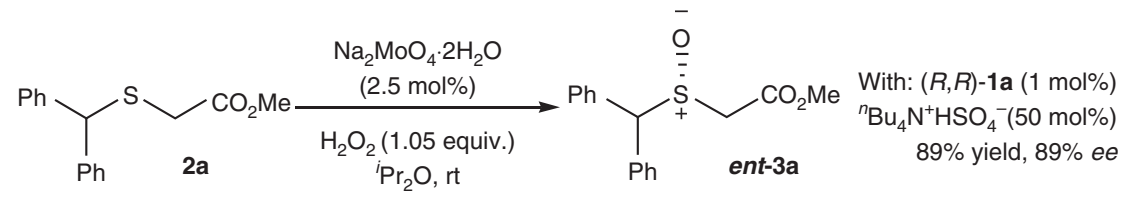

Figure 8 | Effect of achiral tetrabutylammonium cation. Evaluation of selectivity using 50 mol\% of ${ }^{n} \mathrm{Bu}_{4} \mathrm{NHSO}_{4}$ as achiral ion-pairing reagent with $1 \mathrm{~mol} \%$ of chiral catalyst $(R, R)-\mathbf{1 a}$.

between dicationic bisguanidinium, oxodiperoxomolybdosulfate anion, as well as the substrates in the stereoselectivity determining transition state (Supplementary Fig. 5) ${ }^{33,54}$.

\section{Discussion}

In the present study, we have described the first catalytic use of peroxomolybdate for enantioselective sulfoxidation; a series of enantioenriched dialkyl sulfoxides and alkyl aryl sulfoxides have been obtained using inexpensive molybdates and aqueous $\mathrm{H}_{2} \mathrm{O}_{2}$ through a simple experimental protocol. The practical value of current methodology was demonstrated using a gram-scale synthesis of armodafinil, a commercial drug, with a low loading $(0.25 \mathrm{~mol} \%)$ of bisguanidinium. The 'active' catalyst is isolatable, stable and has been identified to be bisguanidinium dinuclear oxodiperoxomolybdosulfate ion pair $[\mathbf{B G}]^{2+}\left[\left(\mu-\mathrm{SO}_{4}\right) \mathrm{Mo}_{2} \mathrm{O}_{2}\right.$ $\left.\left(\mu-\mathrm{O}_{2}\right)_{2}\left(\mathrm{O}_{2}\right)_{2}\right]^{2-}$. Its structure is also unambiguously confirmed by $\mathrm{X}$-ray analysis.

\section{Methods}

General information. The synthesis of sulfide substrates $\mathbf{2}$ are provided in Supplementary Note 1. For the details of mechanistic studies, see Supplementary Figs 3-5, Supplementary Tables 1-2 and Supplementary Note 2. For details of X-ray analysis, see Supplementary Figs 6-9, Supplementary Methods and Supplementary Data 2-9. For details of computational studies, see Supplementary Figs 10-13, Supplementary Tables 3-5, Supplementary Methods and Supplementary Data 1 . For the ${ }^{1} \mathrm{H},{ }^{13} \mathrm{C},{ }^{19} \mathrm{~F}$ and ${ }^{95} \mathrm{Mo}$ NMR data, and spectra of the compounds in the article, see Supplementary Figs 14-70 and Supplementary Methods. For the high-performance liquid chromatography spectra of sulfoxide product 3 and 4 in this article, see Supplementary Figs 71-96.

Preparation of ion pair $(\boldsymbol{R}, \boldsymbol{R})-\mathbf{1 b}$. To the solution of $\mathrm{Na}_{2} \mathrm{MoO}_{4} \cdot 2 \mathrm{H}_{2} \mathrm{O}(24.1 \mathrm{mg}$, $0.1 \mathrm{mmol})$ dissolved in $1 \mathrm{M} \mathrm{H}_{2} \mathrm{SO}_{4}(1 \mathrm{ml}), 35 \% \mathrm{H}_{2} \mathrm{O}_{2}(345 \mu \mathrm{l}, 4.0 \mathrm{mmol})$ was added dropwise to give a yellow solution at room temperature. Then the above solution was added dropwise to a solution of $(R, R)-1 \mathrm{a}(56.4 \mathrm{mg}, 0.04 \mathrm{mmol})$ in $\mathrm{Et}_{2} \mathrm{O}(2 \mathrm{ml})$. After vigorously stirring for $15 \mathrm{~min}$, a pale yellow precipitate was formed in the $\mathrm{Et}_{2} \mathrm{O}$ layer. After further stirring for $2 \mathrm{~h}$ and removal of $\mathrm{Et}_{2} \mathrm{O}$ by evaporation, $4 \mathrm{ml}$ deionized water was added and the resulting heterogeneous mixture was submitted to ultrasound for $1 \mathrm{~min}$. Then the pale yellow solid was filtered off and washed with deionized water $(40 \mathrm{ml})$. After drying over concentrated $\mathrm{H}_{2} \mathrm{SO}_{4}$ under vacuum at room temperature, $(R, R)$-1b was obtained as a pale yellow powder $(65.5 \mathrm{mg}, 91 \%$ yield) and its structure was characterized and determined by X-ray single-crystal diffraction. Increase of the amount of $\mathrm{Na}_{2} \mathrm{MoO}_{4} \cdot 2 \mathrm{H}_{2} \mathrm{O}$ to 0.1 equivalent or replacement of $1 \mathrm{M} \mathrm{H}_{2} \mathrm{SO}_{4}$ with 0.5 equivalent of solid $\mathrm{KHSO}_{4}$ all led to the formation of identical complex $(R, R)-\mathbf{1} \mathbf{b}$, which is confirmed by X-ray diffraction analysis.

General procedure for synthesis of sulfoxides 3. A $10 \mathrm{ml}$ round-bottom flask (RBF) was charged with a solution of sulfide $2(0.2 \mathrm{mmol})$ and bisguanidinium phase-transfer catalyst $(S, S)-\mathbf{1 a}(2.8 \mathrm{mg}, 0.002 \mathrm{mmol})$ in ${ }^{i} \mathrm{Pr}_{2} \mathrm{O}(4 \mathrm{ml})$. Then $\mathrm{Na}_{2} \mathrm{MoO}_{4} \cdot 2 \mathrm{H}_{2} \mathrm{O}(1.2 \mathrm{mg}, 0.005 \mathrm{mmol})$ and $\mathrm{KHSO}_{4}(13.6 \mathrm{mg}, 0.1 \mathrm{mmol})$ were added. The reaction mixture was stirred for $5 \mathrm{~min}$ in an ice bath, and then aqueous $35 \% \mathrm{H}_{2} \mathrm{O}_{2}(18.1 \mu \mathrm{l}, 0.21 \mathrm{mmol})$ was added in one portion. The resulting mixture was stirred vigorously at $0{ }^{\circ} \mathrm{C}$ and monitored by thin-layer chromatography until 2 was completely consumed. Purification using silica gel column chromatography $\left(\mathrm{CH}_{2} \mathrm{Cl}_{2} / \mathrm{EtOAc}=2: 1\right)$ afforded the desired sulfoxide 3 . Minor changes in the amount of $\mathrm{KHSO}_{4}$ and choice of molybdate salt $\left(\mathrm{K}_{2} \mathrm{MoO}_{4}\right)$ and solvent $\left({ }^{n} \mathrm{Bu}_{2} \mathrm{O}\right)$ were conducted for some substrates to achieve slightly better enantioselectivity.

Gram-scale experiment for synthesis of armodafinil 4. A $250 \mathrm{ml}$ round-bottom flask was charged with a solution of methyl 2-(benzhydrylthio)acetate $2 \mathrm{a}$ ( $1.36 \mathrm{~g}$, $5 \mathrm{mmol})$ and bisguanidinium phase-transfer catalyst $(R, R)-1 \mathbf{a}(17.6 \mathrm{mg}$, $0.0125 \mathrm{mmol})$ in ${ }^{n} \mathrm{Bu}_{2} \mathrm{O}(100 \mathrm{ml})$. Then $\mathrm{Na}_{2} \mathrm{MoO}_{4} \cdot 2 \mathrm{H}_{2} \mathrm{O}(30 \mathrm{mg}, 0.125 \mathrm{mmol})$, $\mathrm{KHSO}_{4}(340 \mathrm{mg}, 2.5 \mathrm{mmol})$ and $35 \%$ aq. $\mathrm{H}_{2} \mathrm{O}_{2}(453 \mu \mathrm{l}, 5.25 \mathrm{mmol})$ were added at room temperature. The resulting mixture was stirred vigorously and monitored by thin-layer chromatography and $\mathbf{2 a}$ was completely consumed within $8 \mathrm{~h}$. Purification using silica gel column chromatography $\left(\mathrm{CH}_{2} \mathrm{Cl}_{2} / \mathrm{EtOAc}=2: 1\right)$ afforded the sulfoxide product ent-3a with $R$ configuration, $1.32 \mathrm{~g}, 91 \%$ yield, $91 \%$ ee. Then the obtained sulfoxide $(1.32 \mathrm{~g}, 4.58 \mathrm{mmol})$ was treated with $2 \mathrm{M}$ ammonical methanol ( $23 \mathrm{ml}, 10.0$ equiv.) and the resulting solution was stirred at room temperature for $24 \mathrm{~h}$. Purification using silica gel column chromatography $\left(\mathrm{CH}_{2} \mathrm{Cl}_{2} / \mathrm{MeOH}=20: 1\right)$ afforded 4 as a white solid, $1.19 \mathrm{~g}, 95 \%$ yield, $91 \% e e$.

Data availability. CCDC $1456987-1456990$ contain the supplementary crystallographic data for this paper. These data can be obtained free of charge from The Cambridge Crystallographic Data Centre via www.ccdc.cam.ac.uk/ data_request/cif. The data that support the findings of this study are available from the corresponding authors on request.

\section{References}

1. Burgess, B. K. \& Lowe, D. J. Mechanism of molybdenum nitrogenase. Chem. Rev. 96, 2983-3012 (1996).

2. Schwarz, G., Mendel, R. R. \& Ribbe, M. W. Molybdenum cofactors, enzymes and pathways. Nature 460, 839-847 (2009).

3. Hille, R., Hall, J. \& Basu, P. The mononuclear molybdenum enzymes. Chem. Rev. 114, 3963-4038 (2014).

4. Nishibayashi, Y. Recent progress in transition-metal-catalyzed reduction of molecular dinitrogen under ambient reaction conditions. Inorg. Chem. 54, 9234-9247 (2015).

5. Yamada, S., Mashiko, T. \& Terashima, S. (Acetylacetonato)[(-)-N-alkylephedrinato dioxomolybdenum, a new class of chiral chelate complexes which catalyze asymmetric epoxidation of allylic alcohol. J. Am. Chem. Soc. 99, 1988-1990 (1977).

6. Kagan, H. B., Mimoun, H., Mark, C. \& Schurig, V. Asymmetric epoxidation of simple olefins with an optically active molybdenum(VI) peroxo complex. Angew. Chem. Int. Ed. 18, 485-486 (1979).

7. Trost, B. M. \& Lautens, M. Molybdenum catalysts for allylic alkylation. J. Am. Chem. Soc. 104, 5543-5545 (1982).

8. Fujimura, O. \& Grubbs, R. H. Asymmetric ring-closing metathesis: kinetic resolution catalyzed by a chiral molybdenum alkylidene complex. J. Am. Chem. Soc. 118, 2499-2500 (1996).

9. Barlan, A. U., Basak, A. \& Yamamoto, H. Enantioselective oxidation of olefins catalyzed by a chiral bishydroxamic acid complex of molybdenum. Angew. Chem. Int. Ed. 45, 5849-5852 (2006).

10. Malcolmson, S. J., Meek, S. J., Sattely, E. S., Schrock, R. R. \& Hoveyda, A. H. Highly efficient molybdenum-based catalysts for enantioselective alkene metathesis. Nature 456, 933-937 (2008).

11. Brito, J. A., Royo, B. \& Gomez, M. An overview of chiral molybdenum complexes applied in enantioselective catalysis. Catal. Sci. Tech. 1, 1109-1118 (2011).

12. Basak, A., Barlan, A. U. \& Yamamoto, H. Catalytic enantioselective oxidation of sulfides and disulfides by a chiral complex of bis-hydroxamic acid and molybdenum. Tetrahedron 17, 508-511 (2006).

13. Tytko, K.-H., Fleischmann, W.-D., Gras, D. \& Warkentin, E. Mo Molybdenum: Hydrous Molybdates of Groups VA to VIB Metals (System Nos. 18 to 52) (Springer, 1985).

14. Tytko, K.-H. \& Gras, D. Mo Molybdenum: Oxomolybdenum Species in Aqueous Solutions (Continued) Oxomolybdenum Species in Nonaqueous Solvents Oxomolybdenum Species in Melts Peroxomolybdenum Species (Springer, 1988).

15. Dickman, M. H. \& Pope, M. T. Peroxo and superoxo complexes of chromium molybdenum, and tungsten. Chem. Rev. 94, 569-584 (1994).

16. Zhou, Z.-H., Hou, S.-Y. \& Wan, H.-L. Peroxomolybdate(VI)-citrate and -malate complex interconversions by $\mathrm{pH}$-dependence. Synthetic, structural and spectroscopic studies. Dalton Trans. 1393-1399 (2004).

17. Dengel, A. C., Griffith, W. P., Powell, R. D. \& Skapski, A. C. Studies on transition-metal peroxo complexes. Part 7. molybdenum(VI) and tungsten(VI) carboxylato peroxo complexes, and the X-ray crystal structure of $\mathrm{K}_{2}\left[\mathrm{MoO}\left(\mathrm{O}_{2}\right)_{2}\right.$ (glyc) $] \cdot 2 \mathrm{H}_{2} \mathrm{O}$. J. Chem. Soc. Dalton Trans. 991-995 (1987).

18. Chakravarthy, R. D., Ramkumar, V. \& Chand, D. K. A molybdenum based metallomicellar catalyst for controlled and selective sulfoxidation reactions in aqueous medium. Green Chem. 16, 2190-2196 (2014). 
19. Salles, L. et al. Crystal structures of three novel dioxotetraperoxodi (molybdenum) heteropolyanions in $\left[\mathrm{PPh}_{4}\right]_{2}\left[\mathrm{R}_{2} \mathrm{SiO}_{2}\left\{\mathrm{Mo}_{2} \mathrm{O}_{2}\left(\mu-\mathrm{O}_{2}\right)_{2}\left(\mathrm{O}_{2}\right)_{2}\right\}\right]$ $\left(\mathrm{R}_{2}=\left(\mathrm{CH}_{3}\right)_{2},\left(i-\mathrm{C}_{4} \mathrm{H}_{9}\right)_{2}\right.$ or $\left.\left(\mathrm{CH}_{3}\right)\left(\mathrm{CH}_{2} \mathrm{Cl}\right)\right)$ and characterization of their tungsten analogues. Polyhedron 26, 4786-4792 (2007).

20. Gresley, N. M., Griffith, W. P., Laemmel, A. C., Nogueira, H. I. S. \& Parkin, B. C. Studies on polyoxo and polyperoxo-metalates part 51: peroxide-catalysed oxidations with heteropolyperoxo-tungstates and -molybdates. J. Mol. Catal. A Chem. 117, 185-198 (1997).

21. Gresley, N. M., Griffith, W. P., Parkin, B. C., White, A. J. P. \& Williams, D. J. The crystal structures of $\left[\mathrm{NMe}_{4}\right]\left[\left(\mathrm{Me}_{2} \mathrm{AsO}_{2}\right)\left\{\mathrm{MoO}\left(\mathrm{O}_{2}\right)_{2}\right\}_{2}\right],\left[\mathrm{NMe}_{4}\right]\left[\left(\mathrm{Ph}_{2} \mathrm{PO}_{2}\right)\right.$ $\left.\left\{\mathrm{MoO}\left(\mathrm{O}_{2}\right)_{2}\right\}_{2}\right],\left[\mathrm{NBu}_{4}{ }_{4}\right]\left[\left(\mathrm{Ph}_{2} \mathrm{PO}_{2}\right)\left\{\mathrm{WO}\left(\mathrm{O}_{2}\right)_{2}\right\}_{2}\right]$ and $\left[\mathrm{NH}_{4}\right]\left[\left(\mathrm{Ph}_{2} \mathrm{PO}_{2}\right)\right.$ $\left.\left\{\mathrm{MoO}\left(\mathrm{O}_{2}\right)_{2}\left(\mathrm{H}_{2} \mathrm{O}\right)\right\}\right]$ and their use as catalytic oxidants. J. Chem. Soc. Dalton Trans. 2039-2045 (1996).

22. Hashimoto, M., Ichida, H. \& Sasaki, Y. Preparation and structure of tetramethylammonium hydrogen triperoxotrimolybdodisulfate trihydrate, $\left[\mathrm{N}\left(\mathrm{CH}_{3}\right)_{4}\right]_{3}\left[\mathrm{H}\left(\mathrm{SO}_{4}\right)_{2}\left(\mathrm{MoO}_{2}\left(\mathrm{O}_{2}\right)\right)_{3}\right] \cdot 3 \mathrm{H}_{2} \mathrm{O}$. J. Coord. Chem. 37, 349-359 (1996).

23. Taube, F., Hashimoto, M., Andersson, I. \& Pettersson, L. Characterisation of aqueous peroxomolybdate catalysts applicable to pulp bleaching. J. Chem. Soc. Dalton Trans. 1002-1008 (2002).

24. Deng, D. L., Helton, M. E., Wang, X. H. \& Zhao, W. Bleaching compositions. US Patent 7,645,302 filed 20 Jan. 2006 and issued 12 Jan. 2010.

25. Salles, L., Robert, F., Semmer, V., Jeannin, Y. \& Bregeault, J.-M. Novel di- and trinuclear oxoperoxosulfato species in molybdenum(VI) and tungsten(VI) chemistry: the key role of pairs of bridging peroxo groups. Bull. Soc. Chim. Fr. 133, 319-328 (1996).

26. Shi, X. \& Wei, J. Preparation, characterization and catalytic oxidation properties of bis-quaternary ammonium peroxotungstates and peroxomolybdates complexes. Appl. Organomet. Chem. 21, 172-176 (2007).

27. Ma, T. et al. Pentanidium-catalyzed enantioselective phase-transfer conjugate addition reactions. J. Am. Chem. Soc. 133, 2828-2831 (2011).

28. Yang, Y. et al. Pentanidium-Catalyzed Enantioselective $\alpha$-Hydroxylation of Oxindoles Using Molecular Oxygen. Org. Lett. 14, 4762-4765 (2012).

29. Zong, L., Ban, X., Kee, C. W. \& Tan, C.-H. Catalytic enantioselective alkylation of sulfenate anions to chiral heterocyclic sulfoxides using halogenated pentanidium salts. Angew. Chem. Int. Ed. 53, 11849-11853 (2014).

30. Zong, L., Du, S., Chin, K. F., Wang, C. \& Tan, C.-H. Enantioselective synthesis of quaternary carbon stereocenters: addition of 3-substituted oxindoles to vinyl sulfone catalyzed by pentanidiums. Angew. Chem. Int. Ed. 54, 9390-9393 (2015).

31. Maruoka, K. Asymmetric Phase Transfer Catalysis (Wiley-VCH, 2008).

32. Shirakawa, S. \& Maruoka, K. Recent developments in asymmetric phase-transfer reactions. Angew. Chem. Int. Ed. 52, $4312-4348$ (2013).

33. Brak, K. \& Jacobsen, E. N. Asymmetric ion-pairing catalysis. Angew. Chem. Int. Ed. 52, 534-561 (2013).

34. Mahlau, M. \& List, B. Asymmetric counteranion-directed catalysis: concept, definition, and applications. Angew. Chem. Int. Ed. 52, 518-533 (2013).

35. Phipps, R. J., Hamilton, G. L. \& Toste, F. D. The progression of chiral anions from concepts to applications in asymmetric catalysis. Nat. Chem. 4, 603-614 (2012).

36. Uyanik, M., Okamoto, H., Yasui, T. \& Ishihara, K. Quaternary ammonium (hypo)iodite catalysis for enantioselective oxidative cycloetherification. Science 328, 1376-1379 (2010).

37. Waser, M., Novacek, J. \& Gratzer, K. in Cooperative Catalysis: Designing Efficient Catalysts for Synthesis (ed. Peters, R.) 197-226 (Wiley-VCH, 2015).

38. Wang, C., Zong, L. \& Tan, C.-H. Enantioselective oxidation of alkenes with potassium permanganate catalyzed by chiral dicationic bisguanidinium. J. Am. Chem. Soc. 137, 10677-10682 (2015).

39. Dong, S. et al. Organocatalytic oxyamination of azlactones: kinetic resolution of oxaziridines and asymmetric synthesis of oxazolin-4-ones. J. Am. Chem. Soc. 135, 10026-10029 (2013).

40. Ye, X. et al. Enantioselective sulfoxidation catalyzed by a bisguanidinium diphosphatobisperoxotungstate ion pair. Angew. Chem. Int. Ed. 55, 7101-7105 (2016).

41. Jahier, C. et al. Optically active tripodal dendritic polyoxometalates: synthesis, characterization and their use in asymmetric sulfide oxidation with hydrogen peroxide. Eur. J. Inorg. Chem. 2011, 727-738 (2011).

42. Kagan, H. B. in Organosulfur Chemistry in Asymmetric Synthesis (eds Takeshi, T. \& Carsten, B.) 1-29 (Wiley-VCH, 2009).

43. Bäckvall, J.-E. in Modern Oxidation Methods (ed. Jan-Erling, B.) 277-313 (Wiley-VCH, 2010).
44. Liao, S., Čorić, I., Wang, Q. \& List, B. Activation of $\mathrm{H}_{2} \mathrm{O}_{2}$ by chiral confined brønsted acids: a highly enantioselective catalytic sulfoxidation. J. Am. Chem. Soc. 134, 10765-10768 (2012).

45. Burke, A. J. \& Carreiro, E. P. in Comprehensive Inorganic Chemistry II 2nd edn (ed. Poeppelmeier, K.) 309-382 (Elsevier, 2013).

46. Prisinzano, T., Podobinski, J., Tidgewell, K., Luo, M. \& Swenson, D. Synthesis and determination of the absolute configuration of the enantiomers of modafinil. Tetrahedron 15, 1053-1058 (2004).

47. Rebiere, F., Duret, G., Prat, L. \& Piacenza, G. Process for enantioselective synthesis of single enantiomers of modafinil by asymmetric oxidation. US Patent Application 2005/0222257 filed 17 Mar. 2005, and published 6 Oct. 2005.

48. Ternois, J., Guillen, F., Plaquevent, J.-C. \& Coquerel, G. Asymmetric synthesis of modafinil and its derivatives by enantioselective oxidation of thioethers: comparison of various methods including synthesis in ionic liquids. Tetrahedron 18, 2959-2964 (2008).

49. Hong, L., Sun, W., Yang, D., Li, G. \& Wang, R. Additive effects on asymmetric catalysis. Chem. Rev. 116, 4006-4123 (2016).

50. Firouzabadi, H., Iranpoor, N., Jafari, A. A. \& Riazymontazer, E. Metal-free chemoselective oxidation of sulfides to sulfoxides by hydrogen peroxide catalyzed by in situ generated dodecyl hydrogen sulfate in the absence of organic co-solvents. Adv. Synth. Catal. 348, 434-438 (2006).

51. Miao, C. et al. Proton-promoted and anion-enhanced epoxidation of olefins by hydrogen peroxide in the presence of nonheme manganese catalysts. J. Am. Chem. Soc. 138, 936-943 (2016).

52. Nardello, V., Marko, J., Vermeersch, G. \& Aubry, J. M. ${ }^{95}$ Mo NMR and kinetic studies of peroxomolybdic intermediates involved in the catalytic disproportionation of hydrogen peroxide by molybdate ions. Inorg. Chem. 34, 4950-4957 (1995).

53. Thompson, D. J., Cao, Z., Judkins, E. C., Fanwick, P. E. \& Ren, T. Peroxo-dimolybdate catalyst for the oxygenation of organic sulfides by hydrogen peroxide. Inorg. Chim. Acta 437, 103-109 (2015).

54. Zhao, Y., Cotelle, Y., Sakai, N. \& Matile, S. Unorthodox Interactions at Work. J. Am. Chem. Soc. 138, 4270-4277 (2016).

\section{Acknowledgements}

We acknowledge Nanyang Technological University (M4080946.110, M4011372.110) for financial support. We thank Ms E.L. Goh for her technical support in ${ }^{95} \mathrm{Mo}$ NMR analysis.

\section{Author contributions}

L.Z. and C.-H.T designed and conceived the project. L.Z. performed the experiments and analysed the experimental results. C.-H.T and L.Z wrote the manuscript. C.W. and X.Y. contributed to the initial studies. A.M.P.M. and H.H. performed the computational studies. R.G. and Y.L. contributed to the X-ray data collection.

\section{Additional information}

Supplementary Information accompanies this paper at http://www.nature.com/ naturecommunications

Competing financial interests: The authors declare no competing financial interests

Reprints and permission information is available online at http://npg.nature.com/ reprintsandpermissions/

How to cite this article: Zong, L. et al. Bisguanidinium dinuclear oxodiperoxomolybdosulfate ion pair-catalyzed enantioselective sulfoxidation. Nat. Commun. 7, 13455 doi: 10.1038/ncomms13455 (2016).

Publisher's note: Springer Nature remains neutral with regard to jurisdictional claims in published maps and institutional affiliations.

This work is licensed under a Creative Commons Attribution 4.0 International License. The images or other third party material in this article are included in the article's Creative Commons license, unless indicated otherwise in the credit line; if the material is not included under the Creative Commons license, users will need to obtain permission from the license holder to reproduce the material. To view a copy of this license, visit http://creativecommons.org/licenses/by/4.0/

(C) The Author(s) 2016 